\title{
Efficiency of wine grape growers at farm level: a case study
}

\author{
Micael Santos ${ }^{1, a}$, Ana Marta-Costa ${ }^{1}$, Cátia Santos $^{1}$ and Aníbal Galindro ${ }^{1}$ \\ ${ }^{1}$ University of Trás-os-Montes e Alto Douro (UTAD, www.utad.pt) and Centre for Transdisciplinary Development \\ Studies (CETRAD), Portugal \\ ${ }^{a}$ Corresponding author: micaels@utad.pt
}

\begin{abstract}
To determine the key variables of the vineyard efficiency is imperative to account the combined effects of the inputs interactions since they have implications on the overall final production. This paper estimates the productive efficiency of a wine-farm sample from the Douro Demarcated Region (DDR) while identifies economic, social and environmental indicators that characterizes the DDR grape production system. The data was collected by face-to-face surveys performed at farm level to build a pilot study. The majority of the sampled twenty farms are dedicated to mountain viticulture and mainly feature the cordon (simple and double) training system. Through the Data Envelopment Analysis (DEA) method, the productive efficiency of the sampled was performed and the results clinched different efficiency scores. The main explanation is related to the heterogeneity of the adopted production system. In addition, they revealed how grape producers could improve their productive efficiency by adopting particular practices and identifying the key factors of their system.
\end{abstract}

\section{Introduction}

Due to the relatively abundant vineyard area and the melancholic wine history, Portugal assumes itself as an international reference in the wine sector. However, that accomplishment is hauntingly relative since the country seems to be struggling to gain solid relevance in the highly competitive wine market. According to the OIV [1] worldwide data, Portugal is the $11^{\text {th }}$ largest vineyard area (190 thousands of hectares in 2016), $11^{\text {th }}$ wine producer and concerning the exports (both volume and value) Portugal caps the ninth place [1]. Nonetheless, this country watched those rankings deprecate during the period $2012-2016$ since $18 \%$ of the total vineyard vanished and that fact caused an impact on the wine production and volume exports $(15 \%$ and $18 \%$ respectively) [1]. On the other hand, the Portuguese wine exports increased $4 \%$ in value on the aforementioned period [1], suggesting that despite of the smaller volume of wine exported, the value of each bottle of Portuguese wine increased. However, that positive value evolution is still way far from the world's overall export value growth, which is roughly $14 \%$ [1].
Douro Demarcated Region (DDR) is the most important Portuguese wine region capping $22 \%$ and $21 \%$ of the total Portuguese wine production and vineyard area respectively [2,3]. This region is characterized by a steep mountain viticulture known by the coexistence of heterogeneous production systems. Their farms are assembled in several blocks where each block usually features a different variety of grapes and distinctive management endeavours. The steep slopes difficult the mechanization of the production process and obligates the producer to rely on huge amounts of seasonal workers, which are currently scarce due to the severe depopulation and aging of the region. Those challenges substantially increase the costs of producing grapes in DDR resulting in foregoing lower productivity [4]. One of the main costs of producing wine comes from viticulture, therefore, improving the efficiency at the grape-growing level can have an important impact on the commercial success of the Portuguese wine sector. This paper also aims the recognition of economic, social and environmental indicators, which are able to characterize the grape production system of DDR farms and estimate their productive efficiency afterwards. 
The article is divided in five sections. Besides the overview of the main objective, the following section introduces the notion of productive efficiency, with a brief literature revision. The used methodology is described in section three and the gathered results in section four. Finally, section five summarizes the main conclusions and suggestions for further research.

\section{Productive Efficiency}

Pioneering studies of productive efficiency literature starts with the works of Koopmans [5] and Debreu [6]. The first introduced the concept of technical efficiency (TE) and Debreu [6] developed the first measure of technical efficiency designed as "coefficient of resource utilization". Afterwards, Farrel [7] announced the frontier model to measure the economic efficiency (EE) broken down in TE and allocative efficiency (AE). The first (TE) states that when a certain level of inputs is given and the Decision Making Unit (DMU) is able to produce the maximum level of outputs or, fixing a certain level of output, the DMU is able to minimize the level of input $[5,8,9]$. The AE reflects the ability of a firm to use the inputs in their optimal proportions (given their respective prices) to minimize the cost or maximize the revenue $[8,10]$. There is also another type, which is the scale efficiency that tells us if a DMU is operating on an optimal scale [11].

Several studies have already estimated the productive efficiency in wine sector. Marta-Costa et al. [12], Freitas [13], Coelli and Sanders [14], Moreira et al. [15] and Henriques et al. [16] put their efforts into studies that aim the efficiency calculation of the grape producers, while Sellers-Rubio et al. [17], Sellers-Rubio \& Más-Ruiz [18] and Aparicio et al. [10] studied the efficiency at the wineries level. Urso et al. [19] acquaint the efficiency of grape and wine producers in the same paper. Tóth \& Gál [20] research the efficiency of wine producers at a country level and Vidal et al. [21] study the efficiency of the different denomination of origin (DO) existing in Spain.

The most popular variables among several studies are the grapes (quantity) and the general wine production (quantity or value). Tóth \& Gal [20], Coelli \& Sanders [14], Moreira [15] and Freitas [13] studied the quantity of output produced, while Marta-Costa et al. [12], Urso et al. [19], Sellers-Rubio et al. [17], Sellers-Rubio \& Más-Ruiz [18], Aparicio et al. [10], Vidal et al. [21] and Henriques et al. [16] studied the value of output that was produced. Regarding the input variables, there are three variables mostly used in the precedent articles: labour, capital and land. In addition, some studies considered other inputs such as the intermediate consumption, total specific costs and irrigation [12-14] even though irrigation is only important for dryland agriculture [14].

The variables used to determine the causes of inefficiency in the wine sector are not consensual. Some are related to inner characteristics, such as the size of the farm and the farmer's gender, age education $[16,19,22]$. Meanwhile other efforts pointed out other features such as the diversification/specialization of products $[14,16]$, irrigation $[14,16,22]$, credit access, quality of human capital and per capita wine consumption [23].

\section{Methodology}

This work uses the Data Envelopment Analysis (DEA) method to estimate the productive efficiency in twenty vineyard farms from DDR. In order to identify the best practices in grapes production, we assumed that the farmers were following a cost minimizing (inputorientation) strategy.

The input oriented model considers that a company will be efficient if given certain availability of outputs that company is able to minimize the available resources (inputs). Bearing in mind that the input and output oriented models estimate exactly the same frontiers, in the end they will be able to label the same companies as the efficient ones [18]. The problem of the farmer is the selection of a minimal but admissible input combination without jeopardizing the yield [24].

We assume that any farm $j(j=1,2,3 \ldots n)$ produced a single output $y_{r}$ (grape yield) using a combination of inputs $x_{i j}$. Following the constant returns to scale (CRS) input-oriented DEA model used by Cooper et al. [25], the efficiency of a farm relative to other farms is calculated using the following model (equation 1):

$$
\text { minimize } \theta-\left(\sum_{r} s_{r}^{+}+\sum_{i} s_{i}^{-}\right)
$$

Subject to following constraints,

$$
\begin{aligned}
& \sum_{j=1}^{n} x_{i j} \lambda_{j}+s_{i}^{-}=\theta_{0} x_{i 0}, \quad i=1,2, \ldots, m \\
& \sum_{j=1}^{n} y_{r j} \lambda_{j}-s_{i}^{+}=y_{r 0}, \quad r=1,2, \ldots, s \\
& \lambda_{j}, s_{r}^{-}, s_{r}^{+} \geq 0 ; \forall_{i j}, j, r
\end{aligned}
$$

where $x_{i j}$ and $y_{r j}$ are inputs and outputs respectively, which were defined earlier; $\lambda_{j}$ is the vector of weights of the efficient farms helping in projection of inefficient farms to an efficient frontier (i.e. the distance of 
inefficient farms from the frontier); $\theta$ is an index of farm's technical efficiency.

However, a typical variable-return to-scale (VRS) is considered in reality farming activity because of the potential economies of scale [26]. Banker et al. [27] extended the earlier work of Charnes et al. [28] including an extra constraint $\sum_{j} \lambda_{j}=1$ in equation (1) leading to a VRS frontier. The TE obtained in CRS DEA model is divided into two components obtained by VRS DEA model (equation 2).

$$
T E_{C R S}=T E_{V R S} \times S E
$$

The second step studies the determinants of the inefficiency on farms alongside a brief econometric analysis with a Tobit model that can be expressed by equation (3) [19].

$$
\theta_{j}=\alpha+X_{j} \vec{\beta}+\varepsilon_{j} j=1,2, \ldots, N
$$

where $\theta_{j}$ is the efficiency level of the $j$-th farm obtained by DEA, $\alpha$ is the estimated coefficient for the intercept, $X_{j}$ is a matrix assembled by the explanatory variables of the respective vectors, $\beta$ is a vector of the estimated coefficients, and $\varepsilon_{j}$ is the stochastic error.

The data was gathered from a sample of 20 Portuguese grape producers by a structured face-to-face survey that was conducted with the owners or managers of the DDR holdings. This data is a preliminary sub-sample of the database that is being developed based on criteria such distinct spatial distribution in DDR and diversity of farms dimension and corresponding to the agricultural season of 2016-2017.

The used output variable was the grape production revenue in euros and the used inputs variables were the land (ha), labour (days), capital (euros) and intermediate consumption (euros). The determinants of the efficiency of farms used in tobit model were the vineyard area (ha), farmers' age, the grape production as the main source of income, the training systems adopted (cordon and guyot), and the vineyard landscaping (walled terraces/socalcos, patamares, vertical planting and plan). The studied grape farms have an overall average size of 14,75 ha but accounting only the space dedicated singularly to grapevines that value drops to 9,42 ha. In addition, there is a substantial disparity among the size of farms, since the smallest farm has only 1,96 ha and largest one farm caps a total area of 24,43 ha of vineyard. As stated before the farms on DDR are usually divided in several blocks, that fact is confirmed by the sample mean value of 4,75 blocks within vineyard area.

Most of the grapes are produced using the cordon training system $(75 \%)$, while only $25 \%$ selected the alternative guyot training system. According to the vineyard landscaping, the most are in levelled upland ("Patamares", 55\%), followed by vertical planting $(23 \%)$, plan $(11 \%)$, walled terraces $(5 \%)$ and $\operatorname{mix}$ situations (5\%).

\section{Results}

The average values of the indicators from economic, social and environmental dimensions for the 20 studied farms are presented in Table 1, 2 and 3, respectively. The grapes production average is $4985 \mathrm{~kg}$ per ha but there are distinct productivities among farms, due to the production cycle of the vineyard and the productive system adopted. In addition, the corresponding revenue levels (without subsidies) are different due to the distinct prices payed to the high-quality grapes for Port and DO wines production. Summarily, the results show greater benefit/costs ratio for farms that adopt different training systems in their blocks (mixt), followed by the farms with only cordon system.

Table 1. Economic indicators of the studied grape farms

\begin{tabular}{|c|c|c|c|c|}
\hline $\begin{array}{c}\text { Training } \\
\text { system }\end{array}$ & Cordon & Guyot & Mix & Total \\
\hline $\begin{array}{l}\text { Grape } \\
\text { production } \\
(\mathrm{kg} / \mathrm{Ha}) \\
\end{array}$ & 4873 & 4042 & 6057 & 4985 \\
\hline $\begin{array}{l}\text { Revenue } \\
(€ / \mathrm{Ha})\end{array}$ & 3251 & 2798 & 4015 & 3336 \\
\hline $\begin{array}{l}\text { Capital } \\
(€ / \mathrm{Ha})\end{array}$ & 51234 & 29360 & 47167 & 47139 \\
\hline $\begin{array}{l}\text { Intermediate } \\
\text { Consumption } \\
(€ / \mathrm{Ha})\end{array}$ & 1078 & 1470 & 1426 & 1206 \\
\hline $\begin{array}{l}\text { Real costs } \\
(€ / \mathrm{Ha})\end{array}$ & 3301 & 3256 & 2937 & 3221 \\
\hline $\begin{array}{l}\text { Benefit/cost } \\
\text { Ratio }\end{array}$ & 1,22 & 0,89 & 1,54 & 1,23 \\
\hline $\begin{array}{l}\text { Grape } \\
\text { production as } \\
\text { main source } \\
\text { of income }(\%)\end{array}$ & 46 & 33 & 75 & 50 \\
\hline
\end{tabular}
(2017)

Regarding the social domain (Table 2), the selected indicators bundled the farmers, education and age. The farmers have an average age of 50 years old and $55 \%$ of them have high education. In addition, the farmers with total dedication to vineyard, prospect of increasing or 
maintaining vineyard area and willingness to continue the viticulture were considered. Moreover, $95 \%$ of the farmers intend to continue the viticulture activity and there are only $65 \%$ that fully dedicate themselves to this sector (without parallel professional activities). The farmers majority (80\%) intend to at least maintain or even increase the vineyard area of the farm in the upcoming years. 
Table 2. Social indicators of the studied grape farms (2017)

\begin{tabular}{lcccc}
\hline \multicolumn{1}{c}{ Training system } & Cordon & Guyot & Mix & Total \\
\hline Labour (days/Ha) & 70 & 74 & 81 & 73 \\
\hline $\begin{array}{l}\text { Farmers with } \\
\text { high school (\%) }\end{array}$ & 62 & 67 & 25 & 55 \\
\hline Farmers age & 47 & 47 & 62 & 50 \\
\hline $\begin{array}{l}\text { Farmers with } \\
\text { total dedication to } \\
\text { vineyard (\%) }\end{array}$ & 54 & 67 & 100 & 65 \\
\hline $\begin{array}{l}\text { Prospect of } \\
\text { increasing or } \\
\text { maintaining } \\
\text { vineyard area (\%) }\end{array}$ & 77 & 67 & 100 & 80 \\
\hline $\begin{array}{l}\text { Continuity on } \\
\text { viticulture (\%) }\end{array}$ & 100 & 100 & 75 & 95 \\
\hline Activity heirs (\%) & 46 & 67 & 75 & 55 \\
\hline
\end{tabular}

The results from the studied farms within the environmental dimension (Table 3) show that the Patamares and vertical planting dominate the vineyard landscaping due to their slopes, as showed by the physiographic index. All farms with guyot system adopted the integrated farming and the crop protection assumes lower values per ha.

Table 3. Environmental indicators of the studied grape farms (2017)

\begin{tabular}{lcccc}
\hline Training system & Cordon & Guyot & Mix & Total \\
\hline $\begin{array}{l}\text { Fertilizations } \\
(€ / \text { Ha) }\end{array}$ & 157 & 308 & 161 & 181 \\
\hline $\begin{array}{l}\text { Crop protection } \\
(€ / \text { Ha) }\end{array}$ & 422 & 402 & 510 & 437 \\
\hline $\begin{array}{l}\text { Integrated } \\
\text { farming (\%) }\end{array}$ & 85 & 100 & 75 & 85 \\
\hline $\begin{array}{l}\text { Organic farming } \\
\text { (\%) }\end{array}$ & 8 & 0 & 0 & 5 \\
\hline Soil analysis (\%) & 85 & 100 & 100 & 90 \\
\hline $\begin{array}{l}\text { Favourable waste } \\
\text { destination (\%) }\end{array}$ & 92 & 67 & 100 & 90 \\
\hline $\begin{array}{l}\text { Physiographic } \\
\text { index of the } \\
\text { landscape (IQFP) }\end{array}$ & 2,7 & 0,6 & 1,8 & 2,2 \\
\hline $\begin{array}{l}\text { Walled Terraces } \\
(\text { Socalcos) (\%) }\end{array}$ & 8 & 0 & 4 & 5 \\
\hline Patamares (\%) & 53 & 81 & 34 & 55 \\
\hline $\begin{array}{l}\text { Vertical planting } \\
\text { (\%) }\end{array}$ & 23 & 5 & 44 & 23 \\
\hline Traction (H/Ha) & 30 & 34 & 38 & 32 \\
\hline
\end{tabular}

Table 4 shows some descriptive statistics of the sample of the 20 studied grape farms and Table 5 shows the results of the productive efficiency estimation trough DEA using the STATA 14 software [29].
Table 4. Descriptive statistics of variables for the studied grape farms

\begin{tabular}{lcccc}
\hline \multicolumn{1}{c}{ Variables } & Mean & Std. dev. & Min & Max \\
\hline $\begin{array}{l}\text { Grapes } \\
\text { production }(€)\end{array}$ & 32702,5 & 30293,1 & 5875 & 128819 \\
\hline Vineyard area (ha) & 9,42 & 6,81 & 1,96 & 24,43 \\
\hline Labour (days) & 586,39 & 375,93 & 213,25 & 1575 \\
\hline $\begin{array}{l}\text { Intermediate } \\
\text { costs }(€)\end{array}$ & 17623,35 & 28470,25 & 1288 & 123467 \\
\hline Capital $(€)$ & 404144,5 & 344361,1 & 64795 & 1259041 \\
\hline
\end{tabular}

The average of overall $\mathrm{TE}\left(\mathrm{TE}_{\mathrm{CRS}}\right)$ of grape production is $75,65 \%$, and it ranged from $35 \%$ to $100 \%$. The most efficiency farms are described as DMU 1, 6, 14, 17, 18 and 20. In the VRS analysis, as expected, there are higher levels of pure TE ( $\mathrm{TE}_{\mathrm{VRS}}$ ), where ten farms have a score of $100 \%$. The average of $\mathrm{TE}_{\mathrm{VRS}}$ is $91,38 \%$ and it ranges from $42,39 \%$ to $100 \%$. The presence of scale efficiency (SE) was proved by larger average value of $\mathrm{TE}_{\mathrm{VRS}}$ than $\mathrm{TE}_{\mathrm{CRS}}$ and the average of $\mathrm{SE}$ is $83,02 \%$.

The results shows that the performance of the farms is uneven due to the high levels of inefficiency of some farms compared to the best practices of the farms with the highest levels of the efficiency. The low efficient levels of farms (12 and 19) is due to the pure TE and to the SE, respectively. Thirteen farms exhibit increasing returns to scale, six exhibit constant returns to scale and only one exhibit decreasing returns to scale.

Table 5. Efficiency scores of grape farms

\begin{tabular}{ccccc}
\hline DMU & TE $_{\text {CRS }}$ & TE $_{\text {VRS }}$ & SE & RTS \\
\hline 1 & 1,000000 & 1,000000 & 1,000000 & - \\
\hline 2 & 0,790624 & 0,925318 & 0,854435 & irs \\
\hline 3 & 0,735250 & 1,000000 & 0,735250 & irs \\
\hline 4 & 0,763829 & 0,957323 & 0,797881 & irs \\
\hline 5 & 0,536637 & 1,000000 & 0,536637 & irs \\
\hline 6 & 1,000000 & 1,000000 & 1,000000 & - \\
\hline 7 & 0,557135 & 0,895958 & 0,621832 & irs \\
\hline 8 & 0,997661 & 1,000000 & 0,997661 & irs \\
\hline 9 & 0,573671 & 0,753590 & 0,761251 & irs \\
\hline 10 & 0,620784 & 0,978312 & 0,634545 & irs \\
\hline 11 & 0,909096 & 0,909248 & 0,999833 & irs \\
\hline 12 & 0,363374 & 0,423914 & 0,857187 & irs \\
\hline 13 & 0,544799 & 1,000000 & 0,544799 & irs \\
\hline 14 & 1,000000 & 1,000000 & 1,000000 & - \\
\hline 15 & 0,692430 & 0,743937 & 0,930765 & irs \\
\hline 16 & 0,694269 & 0,714644 & 0,971489 & drs \\
\hline 17 & 1,000000 & 1,000000 & 1,000000 & - \\
\hline 18 & 1,000000 & 1,000000 & 1,000000 & - \\
\hline 19 & 0,350069 & 0,973369 & 0,359647 & irs \\
\hline 20 & 1,000000 & 1,000000 & 1,000000 & - \\
\hline Mean & 0,7564814 & 0,9137807 & 0,8301606 & \\
\hline & & & &
\end{tabular}


Irs: increasing returns to scale; drs: decreasing returns to scale.

Table 6 shows the tobit model results for TE $E_{V R S}$. The results reveals that size has a directly effect on the pure TE, therefore larger vineyard area originates more efficient farms. The age has a negative relationship with the efficiency performance of the farm, revealing that the farmer aging lowers the performance of the farm. In addition, farms that have grape production as the main source of income have lowers levels of pure TE. Regarding to the training systems, the results reveal that guyot and cordon have a negative influence on the efficiency, however only the coefficient of cordon variable is statistically significant at 5\%. For the vineyards landscaping, all coefficients show lowers levels of $\mathrm{TE}_{\mathrm{VRS}}$, but only the vertical planting is statistically significant at $1 \%$. It should be detached, that farms that used a mix of training systems and several vineyard landscaping had a positive effect on the farm efficiency.

Table 6. Tobit model results for $\mathrm{TE}_{\mathrm{VRS}}$

\begin{tabular}{ll}
\hline Variables & Coefficient \\
\hline Constant & $2,137537 * * *$ \\
\hline Vineyard area & 0,0056197 \\
\hline Farmers' age & $-0,0064585$ \\
\hline Grape as main source of income & $-0,167565$ \\
\hline Guyot training system & $-0,3896096$ \\
\hline Cordon training system & $-0,403977 * *$ \\
\hline Walled terraces/Socalcos & $-0,0602633$ \\
\hline Patamares & $-0,4470291$ \\
\hline Vertical planting & $-0,6721773 *$ \\
\hline Plan & $-0,4935155$ \\
\hline Statistically variables: ${ }^{*=10 \% ; *=5 \% ; * *=1 \%}$
\end{tabular}

\section{Conclusion}

The challenge of maintaining or improving agricultural productivity in DDR is enormous. Researchers and policy-makers are constantly looking for technologies that are economically and environmentally attractive to improve the efficiency of the farms. In this experimental work, the TE estimation elucidates that the majority of the sampled farmers are not efficiently using the available technology.

The mean of overall TE of the 20 farms from DDR is $75,65 \%$, revealing that farms could reduce $24,45 \%$ of the used inputs in average. However, this efficiency is very unequal between farms, some with high levels while less than $40 \%$ have low efficiency. In average, these levels are mainly due to the scale efficiency, therefore farms are not operating at the efficient size.

About the determinants of the efficiency, some production practices proved to be more efficiency. For the 20 farms of the sample, the ones that use a mix of guyot and cordon training systems have better efficiency performances and cordon system seems to be the most inefficient. The same occurs in the vineyard landscaping, the farms that feature several systems appears to have better efficient performances and the vertical planting has a stronger negative relationship with efficiency. In addition, the farmers' age and their full dedication to the vineyard activity have negative influence on pure TE, while the size of vineyard area increase the efficiency scores.

To highlight that all results and conclusions of this work were obtained and studied for the twenty farms sample and cannot be extrapolated for DDR.

\section{References}

1. OIV (International Organisation of Vine and Wine), OIV Statistical Report on World Vitiviniculture: World Vitiviniculture Situation. Available at http://www,oiv,int/public/medias/5479/oiv-en-bilan2017,pdf (accessed at 28/02/2017) (2017)

2. IVV (Instituto do Vinho e da Vinha), Evolução da Área de Vinha. Available at www,ivv,minagricultura,pt/np4/35/ (accessed at 27/02/17) (2017)

3. IVV (Instituto do Vinho e da Vinha), Evolução da Produção Nacional de Vinho por Região Vitivinícola. Available at www,ivv,minagricultura,pt/np4/35/ (accessed at 27/02/17) (2017)

4. J. Rebelo, Rumo Estratégico para o setor dos vinhos do Porto e Douro, 117-120 (2017)

5. T.C. Koopmans, Analysis of Production and Allocation, 33-97 (1951)

6. G. Debreu, Econometrica 22, 14-22 (1951)

7. M.J. Farrell, Journal of the Royal Statistical Society, Series A (General) 120 (3), 253-290 (1957)

8. B.E. Bravo-Ureta, D. Solís, V.H.M. López, J.F. Maripani, A. Thiam; T. Rivas, Journal of productivity Analysis 27 (1), 57-72 (2007)

9. E. Fleming, S. Mounter, B. Grant, G. Griffith, R. Villano, Wine Economics and Policy 3 (2), 115-126 (2014)

10. J. Aparicio, F. Borras, J.T. Pastor, F. Vidal, European Journal of Operational Research 231 (2), 443-451 (2013)

11. B. Anang \& A. Rezitis, 2016, Economics Bulletin, 36(4), 2275-2290 (2016)

12. A. Marta-Costa, V. Martinho, M. Santos, Regional Science Inquiry 9 (2), 97-107 (2017) 
13. R. Freitas, Sobre a eficiência dos países produtores de uvas para vinho na União Europeia: uma aproximação DEA em duas etapas (2014)

14. T. Coelli, O. Sanders, Wine Economics, Quantitative Studies and Empirical Applications, 231-249 (2013)

15. V.H. Moreira, J.L. Troncoso, B.E. Bravo-Ureta, Ciencia e Investigación Agraria 38 (3), 321-329, (2011)

16.P.D.S. Henriques, M.L.S. Carvalho, R.M.S. Fragoso, New Medit 8 (1), 4-9, (2009)

17. R. Sellers-Rubio, V. Alampi Sottini, S. Menghini, International Journal of Wine Business Research, 28 (1), 59-75 (2016)

18. R. Sellers-Rubio, F.J. Más-Ruiz, Review of Managerial Science 9 (1), 175-196 (2015)

19. A. Urso, G. Timpanaro, F. Caracciolo, L. Cembalo, Wine Economics and Policy (2017)

20. J. Tóth, P. Gál, Studies in Agricultural Economics 116 (2), 95-99 (2014)

21.F. Vidal, J.T. Pastor, F. Borras, D. Pastor, Spanish Journal of Agricultural Research 11 (2), 294-304 (2013)

22. B. Conradie, G. Cookson, C. Thirtle, South African journal of economics 74(2), 334-343 (2006)

23. T. József, G. Péter, Studies in Agricultural Economics 116, 95-99 (2014)

24. G. Murtaza, G.B. Thapa, Journal of Mountain Science 14 (4), $782-794$ (2017)

25. W.W. Cooper, L.M. Seiford, K. Tone, Introduction to data envelopment analysis and its uses: with DEA-solver software and references (2006)

26. A. Ullah, S.R. Perret, Environmental management 54 (2), 288-300 (2014)

27. R.D. Banker, A. Charnes, W.W. Cooper, Management science 30 (9), 1078-1092 (1984)

28. A. Charnes, W.W. Cooper, E. Rhodes, European journal of operational research 2 (6), 429-444 (1978)

29. Y.B. Ji, C. Lee, Data envelopment analysis, The Stata Journal 10 (2), 267-280 (2010)

\section{Acknowledgements}

This work was supported by the R\&D Project INNOVINE \& WINE - Vineyard and Wine Innovation Platform - Operation NORTE -01-0145-FEDER000038, co-funded by the European and Structural Investment Funds (FEDER) and by Norte 2020 (Programa Operacional Regional do Norte 2014/2020), 